\title{
Influence of Wheat Cultivar, Species of Fusarium, and Isolate Aggressiveness on the Efficacy of Fungicides for Control of Fusarium Head Blight
}

\author{
Á. Mesterházy, T. Bartók, and C. Lamper, Cereal Research Nonprofit Company, Wheat Breeding Department, \\ 6701 Szeged, P.O. Box 391, Hungary
}

\begin{abstract}
Mesterházy, Á., Bartók, T., and Lamper, C. 2003. Influence of wheat cultivar, species of Fusarium, and isolate aggressiveness on the efficacy of fungicides for control of Fusarium head blight. Plant Dis. 87:1107-1115.

Attempts to control Fusarium head blight (FHB) with fungicides have been highly variable. Variability is caused by cultivar resistance, fungicide efficacy, fungicide coverage, timing, and pathogen aggressiveness. In this research, fungicides were tested on winter wheat cultivars with different levels of resistance to FHB using different isolates of Fusarium graminearum and $F$. culmorum to evaluate the role of host resistance and isolate aggressiveness on severity of FHB. Fungicides were applied to groups of wheat heads to provide full coverage. Incidence and severity of FHB was measured by the severity of head symptoms, percentage of Fusariumdamaged kernels (FDK), yield loss, and deoxynivalenol (DON) contamination. Development of FHB was affected by fungicides, cultivars, fungal isolates, and most of the two-way interactions of these variables. Among the fungicides tested, those containing tebuconazole tended to be more effective in reducing FHB. Reduction of disease in susceptible cultivars may not be adequate to produce marketable yields under conditions of high disease pressure. In most cases, if a fungicide reduced FHB visual symptoms, similar decreases were detected in yield loss, DON concentration, and FDK reaction. In 1998, an increase in DON contamination compared with the Fusarium check was observed with azoxystrobin and carbendazim on the more susceptible cultivar. This increase in DON with some fungicide requires additional research. Research to develop more resistant cultivars, better spraying technology, and more effective fungicides is also needed.
\end{abstract}

Additional keywords: Fusarium culmorum, Gibberella zeae, mycotoxin, scab, vomitoxin

Hungary produces 1.1 to 1.3 million ha (about 3 million acres) of wheat (Triticum aestivum L.). The average national yield is 3.5 to $5.4 \mathrm{t} / \mathrm{ha}$, but 6 to $9 \mathrm{t} / \mathrm{ha}$ has been reported on some farms. Fusarium head blight (FHB) of wheat, a devastating disease throughout the world, frequently occurs in Hungary. National surveys have been conducted in Hungary for 32 years to monitor the incidence of FHB. In dry years, only 5 to $6 \%$ of the grain is infected, but in years in which environmental conditions are favorable for the development of FHB, the national mean of disease incidence often exceeds $20 \%$. Incidence in some fields reaches $100 \%$. The first major epidemic of FHB was observed in 1970, and subsequent major epidemics were reported in 1979, 1985, 1997, 1998, and 1999. The highest incidence of grain infection across the country was $24.9 \%$ in

Corresponding author: A. Mesterházy

E-mail: akos.mesterhazy@gk-szeged.hu

Financial support of the project was provied by OMFB grants No. 6315 and 6777.

Accepted for publication 8 April 2003.

Publication no. D-2003-0703-01R

(C) 2003 The American Phytopathological Society
1999. In 1998, losses were estimated at $\$ 100$ million, including direct and indirect losses in yield, lower prices, and consequences of deoxynivalenol (DON) contamination (31).

Fungicides have been applied in an attempt to manage the disease, but efficacy has been variable and often unsatisfactory $(1,4,5,8,21-24,33,34,39,41,43,54)$. Most researchers reported less than 50 to $60 \%$ control. In Hungary, Füzi (10) reported efficacy of fungicides at about $30 \%$. Milus and Parsons (37) tested several fungicides against FHB, but did not observe any reduction in symptoms or DON contamination. Generally, the fungicides with triazole chemistry (tebuconazole, metconazole, and bromuconazole) are the most effective compounds $(3,5,6,9,18,31,36)$; however, it was not always possible to reduce the ratio of visibly scabby grain to less than $5 \%$, which is considered necessary for practical control (54).

In addition to reducing yield and grain weight, FHB results in DON contamination of grain. Several reports indicate that products containing tebuconazole reduce the concentration of DON by about $50 \%$ $(2,17,33,47,48)$. We found $(33,35)$ that concentration of DON decreased in proportion to FHB symptoms. For Fusarium sporotrichioides Shreb., Moss and
Frank (38) reported a reduction in $\mathrm{T}-2$ toxin and diacetoxyscirpenol following application of tridemorph at a low rate (0.35 liters/ha, $0.24 .5 \mathrm{~kg}$ a.i./ha), but DON concentration increased at application rates up to 5 times higher (3.75 liters/ha, $2.62 \mathrm{~kg}$ a.i./ha), despite reduced severity of symptoms. Gareis and Ceynowa (11) reported an increased nivalenol contamination following application of tebuconazole. Concentration of DON has been reported to increase following strobilurin application (41). D'Mello et al. (7) concluded that "sublethal doses" of fungicides (rates lower than recommended by the manufacturer), such as carbendazim, tridemorph, difenoconazole, and tebuconazole plus triadimenol, might increase mycotoxin contamination. Ueda and Yoshizawa (51) reported the occurrence of increased DON concentration at a low rate of carbendazim, but reduced concentrations at higher fungicide rates.

These contradictory results of fungicide efficacy in reducing symptoms and on mycotoxin production need clarification. One source of variability in these tests is the species and isolate of Fusarium involved in the complex, which vary in virulence $(30,35)$. Annually, 500 to 600 samples of grain from commercial fields are planted on pentachloronitrobenzene agar (42) to identify the grain infection level of FHB in Hungary. The primary pathogens associated with FHB in Hungary are $F$. graminearum Schwabe, F. culmorum (Wm. G. Smith) Sacc., and $F$. avenaceum (Fr.:Fr.) Sacc. (27). Fourteen species of Fusarium were recovered from isolations from over 4,000 diseased kernels (27). $F$. graminearum $(68 \%)$ and $F$. culmorum $(12 \%)$ were the most frequently isolated species. $F$. poae, $F$. avenaceum, and $F$. sporotrichioides were isolated from less than $2 \%$ of the grains.

The primary objective of this study was to evaluate the efficacy of fungicides on FHB and their influence on DON concentration. In addition, different cultivars and species of Fusarium were included in the test to elucidate their role in FHB severity and fungicide efficacy, and to provide possible explanations for the contradictory results observed in previous research.

\section{MATERIALS AND METHODS}

Experimental design. Winter wheat plots were planted following oil rape (Brassica napus L.) to minimize inoculum 
of Fusarium spp. from debris. The plot size was $5 \mathrm{~m}^{2}$ and wheat was sown at 550 seed $/ \mathrm{m}^{2}$. The plots were planted on 15,18 , and 22 October in 1995, 1996, and 1997, respectively, using a Wintersteiger Øyord planter (Wintersteiger $\mathrm{GmbH}$, Ried, Austria). Two winter wheat cultivars with different levels of resistance to FHB were planted in the first two years and three cultivars the third year. Zombor (moderately susceptible [MS]) and Zugoly (susceptible [S]) were sown in 1996, Táltos (MS) and Zugoly (S) in 1997, and Bence (moderately resistant [MR]), Táltos (MS), and Zugoly (S) in 1998.

The fungicide treatments were replicated four times for each cultivar in a randomized complete block design. Within each fungicide plot, four isolates of Fusarium spp. and an uninoculated control served as subplots (also called microplots). Another treatment was inoculated but was not treated with fungicide, which is referred to as the no-fungicide treatment. There were three replicates of about 20 heads for each subplot in a factorial design.
Fungicide applications. Fungicides were applied at Feekes growth stage 10.5.1 (full flowering) with 0.5-liter hand sprayers with graduated flasks. Each fungicide was applied in $250 \mathrm{ml}$ of water per $5-\mathrm{m}^{2}$ plot, with one-half applied from each side of the plot so that heads were thoroughly covered. This volume is equivalent with 203 liters/acre or 53.7 gal/acre. The rates of active ingredients are given in Table 1 and agree with the official recommendations for commercial field use in Hungary and European Union.

Inoculum production. Cultures of $F$. graminearum and $F$. culmorum were used in this study. Isolates 12377 (from maize seed; Vesztö, Hungary, 1978), 40, and 44 (from wheat grains; Tulln, Austria, 1992) of F. graminearum; and isolates 12375 (from wheat root; Szeged, Hungary, 1978) and 12551 (from wheat stalk; Szeged, Hungary, 1978) of F. culmorum were used in the studies. Four isolates were used each year, but they differed each year (Table 2). Virulence of the four isolates was confirmed prior to testing using a bioassay in petri dishes $(26,28,30)$. Isolates were stored in test tubes on potato dextrose agar under light mineral oil (Soltrol 160) at room temperature. Isolates stored under these conditions remain viable for 3 years and do not lose pathogenicity (29).

The inocula were sprayed the day after fungicide treatment. Inoculum was produced in 10-liter flasks containing liquid Czapek-Dox medium $(30,31)$. The medium was aerated at about 1 liter/min through a glass tube. A cotton plug was used to filter air in order to avoid contamination of the medium by other microorganisms. After 7 days at room temperature $\left(21\right.$ to $\left.24^{\circ} \mathrm{C}\right)$, the suspension was homogenized for $30 \mathrm{~s}$ in a blender.

The concentration of conidia was measured with a Buerker cell counting chamber (MOM; Hungarian Optical Works, Budapest, Hungary). The suspension contained conidia and mycelium fragments that both are capable of forming colonies and infecting plants (50). Mycelial fragments also were present (especially for isolates of $F$. graminearum that sporulate poorly); therefore, the amount of fungal inoculum in the suspension was higher than the actual

Table 1. Fungicides, active ingredients, and application rates of fungicides used in fungicide trials, 1996 to 1998

\begin{tabular}{|c|c|c|c|c|}
\hline \multirow[b]{2}{*}{ Fungicide } & \multirow[b]{2}{*}{ Active ingredient (g/liter) } & \multicolumn{3}{|c|}{ Application rate (liters/ha) ${ }^{\mathbf{a}}$} \\
\hline & & 1996 & 1997 & 1998 \\
\hline Alert $S^{b}$ & Flusilazole 125 + carbendazim 250 & 1.0 & 1.0 & NT \\
\hline Alto Combi $420^{c}$ & Cyproconazole $120+$ carbendazim 300 & 1.0 & NT & NT \\
\hline Amistar & Azoxystrobin 250 & NT & NT & 1.0 \\
\hline Archer $425 \mathrm{Ec}^{\mathrm{e}}$ & Propiconazole 125 + fenpropimorph 375 & NT & 1.0 & 1.0 \\
\hline Caramba SL ${ }^{\mathrm{f}}$ & Metconazole 60 & NT & 1.0 & NT \\
\hline Duettg & Epoxyconazole 125 + carbendazim 125 & NT & NT & 1.0 \\
\hline Falcon $460 \mathrm{EC}^{\mathrm{h}}$ & Tebuconazole $167+$ spiroxamine $250+$ triadimenol 43 & $0.6,1.2$ & 0.6 & $0.6,0.8,1.0$ \\
\hline Folicur BT $=$ F. Top ${ }^{h}$ & Tebuconazole 125 + triadimephon 100 & 1.0 & 1.0 & 1.0 \\
\hline Folicur Plus = Matador ${ }^{\mathrm{h}}$ & Tebuconazole 250 + triadimenole 125 & 1.0 & NT & NT \\
\hline Folicur Solo = Folicur $250 \mathrm{Ec}^{\mathrm{h}}$ & Tebuconazole 250 & 1.0 & 1.0 & 1.0 \\
\hline Granit $\mathrm{Sc}^{\mathrm{i}}$ & Bromuconazole 200 & 1.0 & NT & NT \\
\hline Juwelg & Kresoxim-methyl 125 + epoxyconazole 125 & NT & NT & 1.0 \\
\hline Kolfugo Super ${ }^{\mathrm{j}}$ & Carbendazim 200 & 1.5 & 1.5 & 1.5 \\
\hline Tangog & Epoxyconazole $125+$ tridemorph 375 & NT & 1.0 & NT \\
\hline Folicur BT + Kolfugo Super & Tebuconazole 125 and triadimephon $100+$ carbendizim 200 & NT & $1.0+1.5$ & $1.0+1.0$ \\
\hline
\end{tabular}

${ }^{\text {a }} \mathrm{NT}=$ not tested.

b DuPont, Newark DE USA/BASF Germany.

c Novartis, Basel, Switzerland.

d Zeneca Agrochemicals, Fernhurst, Haslemere, Surrey, United Kingdom.

e Syngenta, Basel, Switzerland.

${ }^{\mathrm{f}}$ Cyanamid, France, now BASF, Luwigshaven, Germany.

g BASF, Ludwigshaven, Germany.

h Bayer, Leverkusen, Germany.

i Aventis, Crop Science Kft, Budapest, Hungary.

j Chinoin RT, Budapest, Hungary.

Table 2. Concentration and aggressiveness of isolates of Fusarium culmorum and F. graminearum used in fungicide trials, 1996 to 1998

\begin{tabular}{|c|c|c|c|c|c|c|}
\hline \multirow[b]{2}{*}{ Isolate } & \multicolumn{2}{|c|}{1996} & \multicolumn{2}{|c|}{1997} & \multicolumn{2}{|c|}{1998} \\
\hline & $\mathrm{CFU} / \mathbf{m l}^{\mathrm{a}}$ & Aggress. $(\%)^{\mathbf{b}}$ & CFU/ml & Aggress. (\%) & CFU/ml & Aggress. (\%) \\
\hline $12551 \mathrm{~F}$. culmorum & $0.7 \times 10^{5}$ & 100 & $\ldots$ & $\ldots$ & $4.5 \times 10^{5}$ & 100 \\
\hline 12375 F. culmorum & $\ldots$ & $\ldots$ & $\ldots$ & $\ldots$ & $1.8 \times 10^{5}$ & 100 \\
\hline $44 F$. graminearum & $5.2 \times 10^{5}$ & 95 & $2.1 \times 10^{5}$ & 91 & $\ldots$ & $\ldots$ \\
\hline $44 F$. graminearum & $2.6 \times 10^{5}$ & 85 & $\ldots$ & $\ldots$ & $\ldots$ & $\ldots$ \\
\hline $40 \mathrm{~F}$. graminearum & $4.3 \times 10^{5}$ & 96 & $1.3 \times 10^{5}$ & 22 & $5.0 \times 10^{5}$ & 86 \\
\hline $12377 \mathrm{~F}$. graminearum & $\ldots$ & $\ldots$ & $3.8 \times 10^{5}$ & 100 & $2.5 \times 10^{5}$ & 92 \\
\hline $12377 \mathrm{~F}$. graminearum & $\ldots$ & $\ldots$ & $1.9 \times 10^{5}$ & 100 & $\ldots$ & $\ldots$ \\
\hline
\end{tabular}

a Concentration of conidia in suspension. Mycelial fragments that were not counted also were present in the suspensions.

${ }^{\mathrm{b}}$ Aggressiveness determined by the percentage of seedling killed after 6 days using the petri dish assay (29). 
concentration of conidia. The inocula were stored at $4^{\circ} \mathrm{C}$ until use.

Inoculation. Arbitrarily chosen groups of approximately 20 flowering heads (Feekes growth stage 10.5.1) were sprayed from each side with the inoculum (about $20 \mathrm{ml}$ for each) using a 1-liter hand sprayer. The heads were covered with a polyethylene bag for $24 \mathrm{~h}$, if temperature was above $20^{\circ} \mathrm{C}$, and for $48 \mathrm{~h}$, if the temperature was less than $20^{\circ} \mathrm{C}$. The uninoculated spikes were sprayed by distilled water and bagged in the same way, and served as controls. The uninoculated groups of heads were sprayed first to avoid possible contamination. No additional moisture was applied to the heads.

As indicated previously, each of the four fungal isolates was applied in triplicate within each main plot $\left(5 \mathrm{~m}^{2}\right)$. The first isolate was inoculated onto heads approximately $0.5 \mathrm{~m}$ from the front of the plot. Subplots within a plot were separated by approximately $0.5 \mathrm{~m}$. Each group of heads was labeled and loosely bound until harvest.

Disease evaluation and yield. Head symptoms were evaluated 10, 14, 18, 22, and 26 days after inoculation on a scale of 0 to 4 , where $0.1=2.5,0.5=12.5,1=25$, $1.5=37.5,2=50,2.5=62.5,3=75,3.5=$ 87.5 , and $4=100 \%$ of the spikelets with FHB symptoms (29). For statistical analyses, the ratings were converted to percentages by multiplying them by 25 , which is in agreement with other FHB rating schemes (45).

At harvest, each group of heads was cut by hand and placed in a separate bag. Ten heads were randomly separated and threshed at a low fan speed so that small, infected grains would not be blown away with the chaff. Moisture of grain was 13 to $16 \%$ at harvest and $12 \%$ at threshing ( 2 to 3 months after harvest). The grain was weighed and the percentage of Fusariumdamaged kernels (FDK) was estimated. Only those kernels with characteristic white or rose discoloration were considered damaged by Fusarium spp. This method is in agreement with the color picture series from Minnesota (19), except the scale was enlarged to $100 \%$ with $10 \%$ intervals. The three samples of grain of an isolate from each plot were pooled for DON analysis (34). Of $6 \mathrm{~g}$ of seed milled,
$5 \mathrm{~g}$ were used for DON analysis. The method for DON analysis was described earlier (35).

Efficacy of each fungicide treatment for FHB, FDK, DON, and yield loss was calculated as a percentage of the inoculated control, where percent $=100-(x / y) \times 100$, where $x=$ value of fungicide treatment and $y=$ value of unsprayed inoculated control. The mean of the percentage of the four variables was used to provide the percentage of overall efficacy.

Statistics. Both a randomized block and nested-factorial design were used for analysis. The severity of FHB, ratio of FDK, and DON values of the noninoculated control groups of heads were zero in all tests; therefore, these data were not included in the analyses. In all tests, the plots that were inoculated with Fusarium spp. without fungicide treatment served as controls to evaluate fungicide effect. The mean fungal isolate from the fungicidetreated subplot was compared with the same fungus in the unsprayed inoculated control. The data for FHB, FDK, and yield loss were averaged for the three groups of heads for an isolate within a $5-\mathrm{m}^{2}$ plot. The

Table 3. Significance of mean square values for yield loss, Fusarium head blight rating (FHB), percentage of damaged kernels (FDK), and concentration of deoxynivalenol (DON) for each source of variation in 1996

\begin{tabular}{|c|c|c|c|c|c|}
\hline \multirow[b]{2}{*}{ Source of variance } & \multirow[b]{2}{*}{ df } & \multicolumn{4}{|c|}{ Mean square values $^{a}$} \\
\hline & & Yield loss & FHB & FDK & DON \\
\hline Fungicide & 9 & $2,720.3 * * *$ & $2,420.3 * * *$ & $2,783.1 * * *$ & $657.6 * * *$ \\
\hline Isolate & 3 & $27,186.3 * * *$ & $22,370.0 * * *$ & $22,869.6^{* * * *}$ & $2,661.6 * * *$ \\
\hline Cultivar & 1 & $31,335.0 * * *$ & $18,483.0 * * *$ & $10,948.0 * * *$ & $1,317.2 * * *$ \\
\hline Fungicide $\times$ isolate & 27 & $76.3 \mathrm{~ns}$ & $107.1 * *$ & $358.4 * *$ & $51.4 * *$ \\
\hline Fungicide $\times$ cultivar & 9 & $168.4^{*}$ & $124.7 * *$ & $461.5^{* *}$ & $138.5^{* * *}$ \\
\hline Isolate $\times$ cultivar & 3 & $960.3 * * *$ & $955.6 * * *$ & $1,390.0 * * *$ & $79.8 * *$ \\
\hline Fungicide $\times$ isolate $\times$ cultivar & 27 & $87.7 \mathrm{~ns}$ & $43.9 \mathrm{~ns}$ & $158.6 \mathrm{~ns}$ & $38.9 \mathrm{~ns}$ \\
\hline Within & 240 & 86.3 & 56.2 & 116.8 & 26.2 \\
\hline Total & 319 & $\ldots$ & $\ldots$ & $\ldots$ & $\ldots$ \\
\hline
\end{tabular}

a Yield loss relative to the uninoculated check; ***,**, and * significant at $P \leq 0.001,0.01$, and 0.05 , respectively; ns $=$ not significant.

Table 4. Effect of fungicides on mean Fusarium head blight (FHB) rating, percentage of damaged kernels (FDK), yield loss, and concentration of deoxynivalenol (DON) across both cultivars and four fungal isolates in 1996

\begin{tabular}{|c|c|c|c|c|c|}
\hline \multirow[b]{2}{*}{ Fungicide (liters/ha) } & \multicolumn{4}{|c|}{ Disease parameter ${ }^{\mathrm{a}}$} & \multirow[b]{2}{*}{ Overall efficacy $(\%)^{\mathrm{h}}$} \\
\hline & FHB (\%) & FDK $(\%)$ & Yield loss (\%) & DON (ppm) & \\
\hline Falcon 1.2 & 23.8 & 14.6 & 28.8 & 7.0 & 59.9 \\
\hline Folicur Plus 1.0 & 23.9 & 15.9 & 30.5 & 7.5 & 57.9 \\
\hline Folicur Solo 1.0 & 24.8 & 19.6 & 30.7 & 11.0 & 51.4 \\
\hline Fol. BT 1.0 & 28.5 & 18.4 & 33.5 & 8.3 & 52.1 \\
\hline Falcon 0.6 & 30.8 & 19.3 & 35.5 & 9.8 & 47.9 \\
\hline Alert 1.0 & 32.4 & 27.1 & 36.6 & 12.3 & 39.3 \\
\hline Alto Combi 1.0 & 36.5 & 29.7 & 44.3 & 11.1 & 34.1 \\
\hline Granit 1.0 & 38.2 & 33.1 & 45.0 & 15.7 & 25.8 \\
\hline Kolfugo Super 1.0 & 38.2 & 32.0 & 43.3 & 12.7 & 30.5 \\
\hline No fungicide ${ }^{c}$ & 51.8 & 43.7 & 58.7 & 22.2 & 0.00 \\
\hline \multicolumn{6}{|l|}{ Mean } \\
\hline All treatments & 32.9 & 25.3 & 38.7 & 11.8 & 39.9 \\
\hline All treatments, no fungicide & 30.8 & 23.3 & 36.5 & 10.6 & 44.4 \\
\hline $\operatorname{LSD}(P \leq 0.05)^{\mathrm{d}}$ & 3.7 & 5.3 & 4.6 & 2.5 & 5.7 \\
\hline Mean fungicide efficacy (\%) & 40.6 & 46.6 & 37.8 & 52.2 & 44.3 \\
\hline
\end{tabular}

a Yield loss relative to the uninoculated check; Fusarium head blight rating based on a 0 -to- 4 scale, where $0=$ no head blight and $4=100 \%$ of the spikelets with head blight.

b The efficacy of each fungicide for each parameter was calculated as a percentage of the inoculated control. The mean percentage of the four parameters is the overall efficacy.

${ }^{\mathrm{c}}$ Inoculated with fungus, but not sprayed with fungicide.

${ }^{\mathrm{d}} \mathrm{LSD}=$ least significant difference. 
mean for the three replicates was used to calculate the percentage difference, which was used in the analysis. For DON, which was from the pooled grains of the three replicates of an isolate within a plot, the concentration was used in the analysis.

The three-way and the single four-way analyses of variance and correlation analyses were conducted by Microsoft Excel (Microsoft Corporation, Redmond, WA). The three-way and four-way analyses were conducted with the functions given by Sváb (49) and Weber (53). Data were analyzed separately by year because cultivars, fungicides, and isolates changed.

\section{RESULTS}

In 1996, fungicides, fungal isolates, and cultivars all had a significant effect on yield loss, FHB, FDK, and DON (Table 3 ). The two-way interactions among these variables, except for the interaction between fungicide and fungal isolate for yield loss, also were significant. The threeway interaction was not significant for any parameter.

All of the fungicide treatments reduced FHB, FDK, yield loss, and DON accumulation compared with the control, and there were significant differences among the fungicides (Table 4). The mean overall efficacy calculated using all four parameters was also different among fungicides. Fungicide treatments that included the active ingredient tebuconazole tended to be more effective in reducing head blight than the other fungicides. Most of the fungicides were more effective than the current standard carbendazim (Kolfugo Super).

There also were significant differences between cultivars for all four parameters.
The percentage of diseased kernels (Table 5 ) and the severity of FHB (Table 6) across all fungicides and fungal isolates were lower for Zombor, the more resistant cultivar, than for the more susceptible Zugoly. Similar results were observed for yield losses and DON accumulation (data not shown). Mean efficacy of the nine fungicides compared with the untreated control for FHB ratings was lower for the susceptible cultivar Zugoly (32\%) than for the more resistant cultivar Zombor (51\%). Mean efficacy of the nine fungicides compared with the untreated control for FDK was $43 \%$ for the susceptible cultivar Zugoly and $52 \%$ for the resistant cultivar Zombor. The results were similar for the other disease evaluation parameters (data not shown).

The fungal isolates also differed in virulence based on results for FHB, FDK,

Table 5. Effect of fungicide, fungal isolate, and wheat cultivar on percentage of Fusarium-damaged kernels in $1996^{\mathrm{a}}$

\begin{tabular}{|c|c|c|c|c|c|c|c|c|c|c|c|}
\hline \multirow[b]{3}{*}{ Fungicide (liters/ha) } & \multicolumn{5}{|c|}{ Zombor } & \multicolumn{5}{|c|}{ Zugoly } & \multirow[b]{3}{*}{ Overall } \\
\hline & \multicolumn{4}{|c|}{ Fungal isolate } & \multirow[b]{2}{*}{ Cv. } & \multicolumn{4}{|c|}{ Fungal Isolate } & \multirow[b]{2}{*}{ Cv. } & \\
\hline & Fc12552 & Fg44 & Fg44 & Fg40 & & Fc12551 & Fg44 & Fg44 & Fg40 & & \\
\hline Falcon 1.2 & 0.1 & 17.5 & 11.4 & 19.5 & 12.1 & 2.5 & 16.0 & 20.6 & 29.4 & 17.1 & 14.6 \\
\hline Folicur Plus 1.0 & 0.1 & 18.8 & 9.5 & 32.5 & 15.2 & 0.3 & 21.9 & 19.5 & 25.0 & 16.7 & 15.9 \\
\hline Folicur Top 1.0 & 0.1 & 22.5 & 11.3 & 12.3 & 11.5 & 2.1 & 26.3 & 32.5 & 40.6 & 25.4 & 18.4 \\
\hline Falcon 0.6 & 0.8 & 20.0 & 16.3 & 25.6 & 15.7 & 0.2 & 29.4 & 27.5 & 35.0 & 23.0 & 19.3 \\
\hline Folicur Solo 1.0 & 0.3 & 26.3 & 7.5 & 27.5 & 15.4 & 0.7 & 30.0 & 30.6 & 33.8 & 23.8 & 19.6 \\
\hline Alert 1.0 & 0.0 & 21.9 & 8.9 & 33.8 & 16.1 & 1.3 & 62.5 & 46.3 & 42.5 & 38.1 & 27.1 \\
\hline Alto Combi 1.0 & 0.2 & 33.1 & 21.3 & 21.3 & 18.9 & 0.2 & 60.6 & 45.6 & 55.0 & 40.4 & 29.7 \\
\hline Kolfugo S 1.5 & 0.1 & 30.6 & 21.3 & 36.9 & 22.2 & 0.9 & 52.5 & 52.5 & 61.3 & 41.8 & 32.0 \\
\hline Granit 1.0 & 0.2 & 55.0 & 23.8 & 46.3 & 31.3 & 0.8 & 48.8 & 45.6 & 44.4 & 34.9 & 33.1 \\
\hline No fungicide ${ }^{b}$ & 2.4 & 51.3 & 38.8 & 53.8 & 36.5 & 3.4 & 67.5 & 60.0 & 72.5 & 50.9 & 43.7 \\
\hline \multicolumn{12}{|l|}{ Mean } \\
\hline All treatments & 0.4 & 29.7 & 17.0 & 30.9 & 19.5 & 1.2 & 41.5 & 38.1 & 43.9 & 31.2 & 25.3 \\
\hline All treatments, no fungicide & 0.2 & 27.3 & 14.6 & 28.4 & 17.6 & 1.0 & 38.7 & 35.6 & 40.8 & 29.0 & 23.3 \\
\hline $\operatorname{LSD}(P \leq 0.05)^{\mathrm{c}}$ & $\ldots$ & $\ldots$ & $\ldots$ & $\ldots$ & 7.5 & $\ldots$ & $\ldots$ & $\ldots$ & $\ldots$ & 7.5 & 5.3 \\
\hline Mean fungicide efficacy (\%) & 91.9 & 46.8 & 62.5 & 47.2 & 51.8 & 70.8 & 42.7 & 40.6 & 43.8 & 43.0 & 46.7 \\
\hline
\end{tabular}

${ }^{\mathrm{a}} \mathrm{Fc}=$ Fusarium culmorum and $\mathrm{Fg}=$ F. graminearum; $\mathrm{Cv}$. = cultivar mean and Overall = overall mean.

$\mathrm{b}$ Inoculated with fungus, but not sprayed with fungicide.

${ }^{\mathrm{c}} \mathrm{LSD}=$ least significant difference.

Table 6. Effect of fungicide, fungal isolate, and wheat cultivar on Fusarium head blight (FHB) severity rating in 1996 ${ }^{\mathrm{a}}$

\begin{tabular}{|c|c|c|c|c|c|c|c|c|c|c|c|}
\hline \multirow[b]{3}{*}{ Fungicide (liters/ha) } & \multicolumn{5}{|c|}{ Zombor } & \multicolumn{5}{|c|}{ Zugoly } & \multirow[b]{3}{*}{ Overall } \\
\hline & \multicolumn{4}{|c|}{ Fungal isolate } & \multirow[b]{2}{*}{ Cv. } & \multicolumn{4}{|c|}{ Fungal isolate } & \multirow[b]{2}{*}{ Cv. } & \\
\hline & Fc12551 & Fg44 & Fg44 & Fg40 & & Fc12551 & Fg44 & Fg44 & Fg40 & & \\
\hline Falcon 1.2 & 6.8 & 22.4 & 13.9 & 26.8 & 17.5 & 7.1 & 39.1 & 27.4 & 47.2 & 30.2 & 23.8 \\
\hline Folicur Plus 1.0 & 3.3 & 25.8 & 12.8 & 19.3 & 15.3 & 8.6 & 39.3 & 34.1 & 47.7 & 32.4 & 23.9 \\
\hline Folicur Solo 1.0 & 6.6 & 28.8 & 9.7 & 34.3 & 19.8 & 6.6 & 35.2 & 29.4 & 47.4 & 29.7 & 24.8 \\
\hline Folicur Top 1.0 & 6.7 & 33.6 & 19.3 & 26.1 & 21.4 & 8.8 & 46.6 & 32.0 & 54.7 & 35.5 & 28.5 \\
\hline Falcon 0.6 & 7.6 & 28.1 & 15.8 & 35.4 & 21.7 & 10.4 & 50.0 & 38.4 & 60.6 & 39.9 & 30.8 \\
\hline Alert 1.0 & 8.7 & 33.3 & 22.1 & 40.5 & 26.2 & 12.8 & 44.4 & 39.1 & 58.3 & 38.6 & 32.4 \\
\hline Alto Combi 1.0 & 6.1 & 38.0 & 25.6 & 39.4 & 27.3 & 14.2 & 60.6 & 45.8 & 62.3 & 45.7 & 36.5 \\
\hline Granit 1.0 & 7.3 & 40.6 & 29.3 & 43.3 & 30.1 & 14.4 & 57.1 & 48.4 & 65.0 & 46.2 & 38.2 \\
\hline Kolfugo 1.5 & 6.6 & 36.8 & 23.8 & 40.8 & 27.0 & 17.8 & 61.0 & 49.9 & 68.9 & 49.4 & 38.2 \\
\hline No fungicide ${ }^{b}$ & 13.4 & 57.3 & 51.3 & 64.0 & 46.5 & 26.9 & 70.9 & 56.8 & 73.9 & 57.1 & 51.8 \\
\hline \multicolumn{12}{|l|}{ Mean } \\
\hline All treatments & 7.3 & 34.5 & 22.4 & 37.0 & 25.3 & 12.8 & 50.4 & 40.1 & 58.6 & 40.5 & 32.9 \\
\hline All treatments, no fungicide & 6.6 & 31.9 & 19.1 & 34.0 & 22.9 & 11.2 & 48.1 & 38.3 & 56.9 & 38.6 & 30.8 \\
\hline $\operatorname{LSD}(P \leq 0.05)^{\mathrm{c}}$ & $\ldots$ & $\ldots$ & $\ldots$ & $\ldots$ & 5.2 & $\ldots$ & $\ldots$ & $\ldots$ & $\ldots$ & 5.2 & 3.7 \\
\hline Mean fungicide efficacy $(\%)$ & 50.7 & 44.3 & 62.7 & 46.9 & 50.7 & 58.4 & 32.1 & 32.6 & 23.0 & 32.4 & 40.6 \\
\hline
\end{tabular}

${ }^{\mathrm{a}}$ FHB rating based on a 0-to-4 scale, where $0=$ no head blight and $4=100 \%$ of the spikelets with head blight. Fc $=$ Fusarium culmorum and Fg $=$ F. graminearum; $\mathrm{Cv} .=$ cultivar mean and Overall $=$ overall mean.

b Inoculated with fungus, but not sprayed with fungicide.

${ }^{c}$ LSD = least significant difference. 
DON, and yield loss (results for FHB and FDK are shown in Tables 5 and 6). Isolate 12551 of $F$. culmorum was less virulent than the other three isolates. Although fungicide efficacy was affected by the fungal isolate, there was no difference between the two species of Fusarium in fungicide efficacy based on the percentage improvement in control of FHB of the fungicides compared with the untreated control. The correlations for FHB ratings among the fungicides between the isolates of $F$. graminearum and $F$. culmorum across cultivars were between $r=0.9287$ and $0.9816(P \leq 0.001)$.

Correlations between FHB ratings, percentage FDK, yield loss, and DON accumulation in response to fungicides were highly significant $(r>0.93 ; P \leq 0.001)$, which indicates that the fungicides had a similar effect on all four parameters. Although the responses were correlated, fungicide efficacy based on the percentage improvement over the unsprayed control was variable for the four disease parameters. Maximum fungicide efficacy was 38, 41,47 , and $52 \%$ for yield loss, FHB rat- ings, percentage of FDK, and DON accumulation, respectively. This variation in efficacy demonstrates the need to consider all four parameters in describing the influence of fungicides on the development of head blight.

Results in 1997 were similar to 1996 (Table 7). Fungicides, fungal isolates, and cultivars had a significant effect on yield loss, FHB, and FDK. The two-way interactions among these variables, except for the interaction between fungicide and fungal isolate for yield loss, also were significant. The three-way interaction was significant only for the percentage of diseased kernels. Results for DON accumulation were different than in 1996. Accumulation of DON was not significant for cultivar or the cultivar-fungal isolate interaction.

The percentage of FDK in 1997 was higher than in 1996, but results for the two years were similar (Table 8). All fungicide treatments reduced FHB, FDK, yield loss, and DON accumulation compared with the unsprayed control, and there were significant differences among the fungicides. There also were differences among fungi- cides in overall mean efficacy based on all four parameters. Among the fungicides, the mixture of tebuconazole and triadimephon plus carbendazim (Folicur Top plus Kolfugo) had the highest overall efficacy $(56 \%)$. As in 1996, fungicide treatments that contained tebuconazole tended to be the most effective.

There also were significant differences between cultivars and fungal isolates for all four parameters. Severity of FHB (Table 9) across all fungicides and fungal isolates was lower for Táltos, the more resistant cultivar, than for the more susceptible cultivar Zugoly. Similar results were observed for reduction in yield loss, FDK, and DON accumulation (data not shown). Isolate 40 of $F$. graminearum was less virulent that the other isolates used in 1997.

As in 1996, correlations between fungicide efficacy for four parameters were significant $(r \geq 0.90, P \leq 0.001)$ in 1997. Maximum efficacy for the most effective fungicide was between 61 and $51 \%$ for the FHB rating, percentage of FDK, relative yield loss, and DON accu-

Table 7. Significance of mean square values for Fusarium head blight (FHB) rating, percentage of damaged kernels (FDK), yield loss, and concentration of deoxynivalenol (DON) for each source of variation in 1997

\begin{tabular}{|c|c|c|c|c|c|}
\hline \multirow[b]{2}{*}{ Source of variation } & \multirow[b]{2}{*}{ df } & \multicolumn{4}{|c|}{ Mean square values $^{\mathrm{a}}$} \\
\hline & & FHB & FDK & Yield loss & DON \\
\hline Fungicide & 9 & $1,494.88 * * *$ & $2,210.11 * * *$ & $2,185.33 * * *$ & $241.28 * * *$ \\
\hline Isolate & 3 & $20,697.33 * * *$ & $70,910.66^{* * *}$ & $38,708.66 * * *$ & $1,854.29 * * *$ \\
\hline Genotype & 1 & $15,443.00^{* * *}$ & $452.00 * * *$ & $2,833.00 * * *$ & $6.09 \mathrm{~ns}$ \\
\hline Fungicide $\times$ isolate & 27 & $154.11^{* * *}$ & $284.92 * * *$ & $78.25 \mathrm{~ns}$ & $35.61 * * *$ \\
\hline Fungicide $\times$ genotype & 9 & $176.88 * * *$ & $621.55^{* * *}$ & $341.88 * * *$ & $70.71 * * *$ \\
\hline Isolate $\times$ genotype & 3 & $1,269.00 * * *$ & $464.83 * * *$ & $914.33 * * *$ & $6.07 \mathrm{~ns}$ \\
\hline Fungicide $\times$ isolate $\times$ genotype & 27 & $31.85 \mathrm{~ns}$ & $121.53 * * *$ & $66.55 \mathrm{~ns}$ & $12.15 \mathrm{~ns}$ \\
\hline Error & 240 & 23.60 & 88.6 & 89.8 & 7.80 \\
\hline Total & 319 & $\ldots$ & $\ldots$ & $\ldots$ & $\ldots$ \\
\hline
\end{tabular}

a Yield loss relative to the uninoculated check; ***,**, and $*$ significant at $P \leq 0.001,0.01$, and 0.05 , respectively; ns $=$ not significant.

Table 8. Effect of fungicides on mean Fusarium head blight rating (FHB), percentage of damaged kernels (FDK), yield loss, and concentration of deoxynivalenol (DON) across both cultivars and four fungal isolates in 1997

\begin{tabular}{|c|c|c|c|c|c|}
\hline \multirow[b]{2}{*}{ Fungicide (liters/ha) } & \multicolumn{4}{|c|}{ Disease parameter ${ }^{\mathbf{a}}$} & \multirow[b]{2}{*}{ Overall efficacy $(\%)^{\mathrm{b}}$} \\
\hline & FHB $(\%)$ & FDK $(\%)$ & Yield loss (\%) & DON (ppm) & \\
\hline Folicur Top $1.0+$ Kolfugo 1.5 & 16.3 & 28.6 & 29.2 & 6.6 & 56.3 \\
\hline Folicur Solo 1.0 & 18.2 & 39.4 & 32.9 & 7.7 & 47.5 \\
\hline Folicur Top 1.0 & 22.8 & 43.9 & 37.9 & 9.9 & 37.3 \\
\hline Falcon 0.6 & 25.7 & 47.3 & 39.9 & 9.9 & 33.4 \\
\hline Archer 1.0 & 26.5 & 49.3 & 39.6 & 9.4 & 44.7 \\
\hline Metconazole 1.0 & 26.5 & 46.3 & 40.5 & 10.2 & 40.0 \\
\hline Alert 1.0 & 27.0 & 48.9 & 45.9 & 8.7 & 31.2 \\
\hline Kolfugo 1.5 & 28.5 & 46.0 & 44.6 & 9.6 & 30.7 \\
\hline Tango 1.0 & 30.5 & 52.1 & 47.3 & 11.7 & 22.6 \\
\hline No fungicide ${ }^{c}$ & 41.1 & 60.6 & 59.1 & 17.0 & 0.0 \\
\hline \multicolumn{6}{|l|}{ Mean } \\
\hline All treatments & 26.3 & 45.9 & 42.1 & 10.1 & 34.4 \\
\hline All treatments, no fungicide & 24.7 & 44.6 & 39.8 & 9.3 & \\
\hline $\operatorname{LSD}(P \leq 0.05)^{\mathrm{d}}$ & 2.4 & 4.6 & 4.6 & 1.6 & 6.51 \\
\hline Mean fungicide efficacy (\%) & 40.0 & 26.3 & 32.7 & 45.3 & 36.1 \\
\hline
\end{tabular}

a Yield loss relative to the uninoculated check; Fusarium head blight rating based on a 0 -to- 4 scale, where $0=$ no head blight and $4=100 \%$ of the spikelets with head blight.

${ }^{b}$ Efficacy of each fungicide for each parameter was calculated as a percentage of the inoculated control. The mean percentage of the four parameters is the overall efficacy.

${ }^{c}$ Inoculated with fungus, but not sprayed with fungicide.

${ }^{\mathrm{d}} \mathrm{LSD}=$ least significant difference. 
mulation, indicating that the fungicides had a similar effect on all four parameters measured.

In 1998, all main effects and two-way interactions were significant for FHB rating, percentage of FDK, yield loss, and concentration of DON (Table 10). The three-way interaction between fungicide, fungal isolate, and cultivar was significant for FHB rating and yield loss.

All of the fungicide treatments reduced FHB, FDK, and yield loss, and there were significant differences among the fungicides. Except for carbendazim (Kolfugo Super) and azoxystrobin (Amistar), all of the fungicides reduced the accumulation of DON (Table 11). Mean overall efficacy based on all four parameters also was different among fungicides. Fungicide treatments that included the active ingredient tebuconazole tended to be more effective in reducing head blight than the other fungicides. The combination of tebuconazole and triadimephon plus carbendazim (Folicur Top plus Kolfugo) had the highest overall efficacy.

Across all fungal isolates, the mean fungicide efficacy for FHB ratings was lower on Zugoly (59\%) than on Bence (70\%) and
Táltos (72\%). Folicur Top + Kolfugo $(82.92 \%)$ and Folicur Solo $(83.7 \%)$ were the most effective in reducing FHB ratings. Similar results were observed for the percentage of FDK. Across all fungal isolates, the mean fungicide efficacy for percentage of FDK was $37.6 \%$ for the susceptible Zugoly, $53.7 \%$ for the intermediately susceptible Táltos, and $74.7 \%$ for the resistant Bence.

There also were significant differences between cultivars and fungal isolates for all four parameters. The results for DON accumulation are presented in Table 12. Accumulation of DON across all fungicides and fungal isolates was lowest for Bence, intermediate for Táltos, and greatest for Zugoly. Similar results were observed for reduction in yield loss, FDK, and DON accumulation (data not shown).

As in 1996 and 1997, correlations between fungicide efficacy of the four parameters measured (FHB ratings, percentage FDK, DON accumulation, and relative yield loss) were significant ( $r=0.92$ and $0.97, P \leq 0.001)$. This indicates that fungicide efficacy was similar for the four parameters measured.

\section{DISCUSSION}

The microplot method used in this study originally was developed for evaluating host plant resistance (29). Many cultivars and fungal isolates could be evaluated at the same time in a relatively small area. This method was easily adapted for the evaluation of fungicides on several cultivars using different isolates of the head scab pathogen.

Efficacy of fungicides in controlling FHB is highly variable and often unsatisfactory $(1,4,5,21-24,33,34,39,41,54)$. Some of the variability in these studies is related to the timing of the fungicide application and coverage (12). Other sources of variability are the timing and severity of infection, virulence of the isolates, and level of resistance in the cultivars planted. Using the microplot method, these sources of variability are eliminated or reduced, which provides an accurate evaluation of fungicide efficacy. Although the microplot technique eliminates or reduces problems with fungicide coverage and timing, results of fungicide efficacy observed in this study should not be expected under field conditions experienced by producers. Producers do not have the benefits of ideal

Table 9. Effect of fungicide, fungal isolate, and wheat cultivar on Fusarium head blight (FHB) ratings in 1997a

\begin{tabular}{|c|c|c|c|c|c|c|c|c|c|c|c|}
\hline \multirow[b]{3}{*}{ Fungicide (liters/ha) } & \multicolumn{5}{|c|}{ Taltos } & \multicolumn{5}{|c|}{ Zugoly } & \multirow[b]{3}{*}{ Overall } \\
\hline & \multicolumn{4}{|c|}{ Fungal isolate } & \multirow[b]{2}{*}{ Cv. } & \multicolumn{4}{|c|}{ Fungal isolate } & \multirow[b]{2}{*}{ Cv. } & \\
\hline & Fg44 & Fg40 & Fg12377 & Fg12377-2 & & Fg44 & Fg40 & Fg12377 & Fg12377-2 & & \\
\hline Folicur Top $1.0+$ Kolf. 1.5 & 14.4 & 0.9 & 17.9 & 10.3 & 10.9 & 24.7 & 2.4 & 38.8 & 20.8 & 21.7 & 16.3 \\
\hline Folicur Solo 1.0 & 16.4 & 1.7 & 17.6 & 13.3 & 12.2 & 28.3 & 4.3 & 39.7 & 23.7 & 24.1 & 18.2 \\
\hline Folicur Top 1.0 & 20.3 & 1.3 & 26.7 & 18.1 & 16.6 & 39.0 & 3.0 & 43.0 & 30.8 & 28.9 & 22.8 \\
\hline Falcon 0.6 & 19.0 & 2.3 & 30.5 & 23.7 & 18.9 & 41.5 & 4.4 & 49.1 & 35.3 & 32.6 & 25.7 \\
\hline Archer 1.0 & 20.6 & 0.2 & 30.1 & 7.0 & 14.5 & 48.8 & 4.8 & 59.8 & 41.0 & 38.6 & 26.5 \\
\hline Metconazole 1.0 & 23.5 & 3.2 & 31.9 & 25.0 & 20.9 & 41.4 & 5.3 & 46.1 & 35.9 & 32.2 & 26.5 \\
\hline Alert 1.0 & 27.7 & 2.6 & 35.7 & 25.3 & 22.8 & 41.3 & 5.6 & 51.0 & 27.2 & 31.3 & 27.0 \\
\hline Kolfugo 1.5 & 17.6 & 2.1 & 31.7 & 21.9 & 18.3 & 45.4 & 8.0 & 60.5 & 40.9 & 38.6 & 28.5 \\
\hline Tango 1.0 & 25.3 & 2.5 & 36.8 & 30.8 & 23.9 & 42.4 & 6.0 & 58.7 & 41.7 & 37.2 & 30.5 \\
\hline No fungicide ${ }^{b}$ & 44.1 & 4.3 & 48.4 & 42.1 & 34.7 & 58.5 & 7.0 & 70.9 & 53.5 & 47.4 & 41.1 \\
\hline \multicolumn{12}{|l|}{ Mean } \\
\hline All treatments & 22.9 & 2.1 & 30.7 & 21.7 & 19.4 & 41.2 & 5.1 & 54.7 & 35.0 & 33.3 & 26.3 \\
\hline All treatments, no fungicide & 20.5 & 1.9 & 28.8 & 19.5 & 17.7 & 39.2 & 4.8 & 49.6 & 33.0 & 31.7 & 24.7 \\
\hline $\operatorname{LSD}(P \leq 0.05)^{\mathrm{c}}$ & & & & & 2.2 & & & & & 2.2 & 1.6 \\
\hline Mean fungicide efficacy (\%) & 60.4 & 56.8 & 40.6 & 53.7 & 49.1 & 33.0 & 30.4 & 30.0 & 38.3 & 33.2 & 39.9 \\
\hline
\end{tabular}

${ }^{a}$ FHB rating based on a 0 -to- 4 scale, where $0=$ no head blight and $4=100 \%$ of the spikelets with head blight. Fc $=$ Fusarium culmorum and Fg $=$ Fusarium graminearum; $\mathrm{Cv} .=$ cultivar mean and Overall $=$ overall mean; Kolf. $=$ Kolfugo.

${ }^{\mathrm{b}}$ Inoculated with fungus, but not sprayed with fungicide.

${ }^{\mathrm{c}} \mathrm{LSD}=$ least significant difference.

Table 10. Significance of mean square values for Fusarium head blight rating (FHB), percentage of damaged kernels (FDK), yield loss, and concentration of deoxynivalenol (DON) within each source of variation in 1998

\begin{tabular}{|c|c|c|c|c|c|c|}
\hline \multirow[b]{2}{*}{ Source of variance } & \multirow[b]{2}{*}{ df } & \multicolumn{4}{|c|}{ Mean square values ${ }^{\mathrm{a}}$} & \multirow[b]{2}{*}{ df for DON (ppm) } \\
\hline & & FHB (\%) & FDK (\%) & Yield loss (\%) & DON (ppm) & \\
\hline Fungicide & 10 & $4,601.25 * * *$ & $5,535.33 * * *$ & $3,968.07 * * *$ & $345.16^{* * *}$ & 9 \\
\hline Cultivar & 2 & $19,243.41 * * *$ & $71,748.72 * * *$ & $18,837.52 * * *$ & $3,838.32 * * *$ & 2 \\
\hline Isolate & 3 & $13,853.55 * * *$ & $23,769.84 * * *$ & $12,488.33 * * *$ & $953.36 * * *$ & 3 \\
\hline Fungicide $\times$ cultivar & 20 & $450.05 * * *$ & $750.13 * * *$ & $305.06 * * *$ & $92.49 * * *$ & 18 \\
\hline Fungicide $\times$ isolate & 30 & $464.98 * * *$ & $431.98 * * *$ & $234.64 * * *$ & $50.42 * *$ & 27 \\
\hline Cultivar $\times$ isolate & 6 & $1,034.48 * * *$ & $2,597.43 * * *$ & $736.66 * * *$ & $212.13 * * *$ & 6 \\
\hline Fungicide $\times$ cultivar $\times$ isolate & 60 & $65.28 * * *$ & 225.4 & $91.17 *$ & $20.12 \mathrm{~ns}$ & 54 \\
\hline Error & 396 & 19.6 & 108.65 & 69.1 & 19.99 & 240 \\
\hline Total & 527 & $\ldots$ & $\ldots$ & $\ldots$ & $\ldots$ & 359 \\
\hline
\end{tabular}

a Yield loss relative to the uninoculated check; ***,**, and $*$ significant at $P \leq 0.001,0.01$, and 0.05 , respectively; ns $=$ not significant. 
coverage and timing of fungicide applications that were achieved with the microplots in this study. These results do, however, demonstrate the potential of these fungicides to control FHB.

In this study, there were differences among fungicides in their ability to reduce FHB. Fungicides that contain tebuconazole as one of the active ingredients tended to be the most effective, but their efficacy was reduced at lower rates (Falcon at 0.6 liter/ha). Other researchers $(14,23,52)$ have reported satisfactory control using tebuconazole, but Hershman et al. (16) reported poor performance. Although bromucona- zole (Granit) and metconazole (Caramba) have been reported to have efficacy against FHB $(3,5,6,20)$, they were only moderately effective in this study. The failure to perform in Hungary may be because the application rate was $33 \%$ less than the application rate in Western European countries. Results with metconazole at 1.2 and 1.5 liters/ha were similar to tebuconazole (Á. Mesterházy, unpublished data).

Carbendazim (Kolfugo Super), which has been the standard fungicide for control of FHB in Hungary over the past 30 years, was one of the least effective fungicides. It has been reported to increase the efficacy of triazole fungicides against FHB $(32,44)$. In this study, although triazoles combined with carbendazim may have been more effective than carbendazim alone, neither was better than fungicides containing tebuconazole. The mixture of tebuconazole + triadimephon (Folicur Top) and carbendazim (Kolfugo Super) was the most effective treatment against FHB in 1997 and 1998. We have observed a similar response previously with tebuconazole + spiroxamine + triadimephon (Falcon at 0.8 liter/ha) + carbendazim (Kolfugo Super at 1 liter/ha) and tebuconazole (Folicur at 1 li-

Table 11. Effect of fungicides on mean Fusarium head blight rating (FHB) in wheat rated for FHB, yield loss, percentage of damaged kernels (FDK), and concentration of deoxynivalenol (DON) across three cultivars and four fungal isolates in 1998

\begin{tabular}{|c|c|c|c|c|c|}
\hline \multirow[b]{2}{*}{ Fungicide (liters/ha) } & \multicolumn{4}{|c|}{ Disease parameters $^{\mathbf{a}}$} & \multirow[b]{2}{*}{ Overall efficacy $(\%)^{\mathbf{b}}$} \\
\hline & FHB (\%) & Yield loss $(\%)$ & FDK $(\%)$ & DON (ppm) & \\
\hline Folicur Top $1.0+$ Kolfugo 1.0 & 7.7 & 16.0 & 15.5 & 4.2 & 70.3 \\
\hline Folicur Solo 1.0 & 8.4 & 20.9 & 19.7 & 3.8 & 68.5 \\
\hline Falcon 0.8 & 9.6 & 20.6 & 28.1 & 6.2 & 59.0 \\
\hline Falcon 1.0 & 11.5 & 18.4 & 25.9 & 5.7 & 62.0 \\
\hline Folicur Top $1.0+$ Kolfugo 1.0 & 12.9 & 21.3 & 30.8 & 5.9 & 55.8 \\
\hline Juwel 1.0 & 13.6 & 30.4 & 28.8 & 5.9 & 53.4 \\
\hline Duett 1.0 & 14.1 & 25.4 & 25.9 & $\ldots$ & $\ldots$ \\
\hline Falcon 0.6 & 16.1 & 28.2 & 35.7 & $\ldots$ & $\ldots$ \\
\hline Kolfugo 1.5 & 23.3 & 38.4 & 41.9 & 10.4 & 34.0 \\
\hline Amistar 1.0 & 24.7 & 37.6 & 46.4 & 11.0 & 26.8 \\
\hline No fungicide $e^{c}$ & 41.0 & 50.4 & 58.6 & 11.8 & 0.0 \\
\hline \multicolumn{6}{|l|}{ Mean } \\
\hline All treatments & 16.5 & 28.0 & 32.5 & 7.2 & 39.1 \\
\hline All treatments, no fungicide & 14.2 & 25.7 & 29.9 & 6.6 & $\ldots$ \\
\hline $\operatorname{LSD}(P \leq 0.05)^{\mathrm{d}}$ & 0.7 & 2.8 & 3.4 & 2.0 & 7.74 \\
\hline Mean fungicide efficacy (\%) & 65.4 & 48.9 & 49.0 & 43.7 & 51.7 \\
\hline
\end{tabular}

${ }^{\text {a }}$ Yield loss relative to the uninoculated check; FHB rating based on a 0 -to-4 scale, where $0=$ no head blight and $4=100 \%$ of the spikelets with head blight.

${ }^{b}$ Efficacy of each fungicide for each parameter was calculated as a percentage of the inoculated control. The mean percentage of the four parameters is the overall efficacy.

${ }^{\mathrm{c}}$ Inoculated with fungus, but not sprayed with fungicide.

${ }^{\mathrm{d}} \mathrm{LSD}=$ least significant difference.

Table 12. Effect of fungicide, fungal isolate, and wheat cultivar on deoxynivalenol contamination (ppm) following fungicide application in $1998^{\text {a }}$

\begin{tabular}{|c|c|c|c|c|c|c|c|c|c|c|c|c|c|c|c|c|}
\hline \multirow[b]{3}{*}{$\begin{array}{l}\text { Fungicide } \\
\text { (liters/ha) }\end{array}$} & \multicolumn{5}{|c|}{ Zugoly } & \multicolumn{5}{|c|}{ Táltos } & \multicolumn{5}{|c|}{ Bence } & \multirow[b]{3}{*}{ Over } \\
\hline & \multicolumn{4}{|c|}{ Fungal isolates } & & \multicolumn{4}{|c|}{ Fungal isolates } & & \multicolumn{4}{|c|}{ Fungal isolates } & \multirow[b]{2}{*}{ Cv. } & \\
\hline & $\begin{array}{c}12377 \\
\text { Fg }\end{array}$ & $\begin{array}{l}40 \\
\text { Fg }\end{array}$ & $\begin{array}{c}12375 \\
\text { Fc }\end{array}$ & $\begin{array}{c}12551 \\
\text { Fc }\end{array}$ & Cv. & $\begin{array}{c}12377 \\
\text { Fg }\end{array}$ & $\begin{array}{l}40 \\
\text { Fg }\end{array}$ & $\begin{array}{c}12375 \\
\text { Fc }\end{array}$ & $\begin{array}{c}12551 \\
\text { Fc }\end{array}$ & Cv. & $\begin{array}{c}12377 \\
\text { Fg }\end{array}$ & $\begin{array}{l}40 \\
\text { Fg }\end{array}$ & $\begin{array}{c}12375 \\
\text { Fc }\end{array}$ & $\begin{array}{c}12551 \\
\text { Fc }\end{array}$ & & \\
\hline $\begin{array}{l}\text { F. Solo } 1.0 \\
\text { F. Top } 1.0+\end{array}$ & 7.6 & 1.2 & 10.3 & 16.6 & 8.9 & 3.3 & 1.3 & 0.0 & 3.1 & 1.9 & 0.0 & 0.0 & 0.0 & 2.0 & 0.5 & 3.8 \\
\hline Kolf. 1.0 & 10.0 & 4.5 & 5.7 & 13.3 & 8.4 & 4.1 & 0.8 & 0.8 & 9.2 & 3.7 & 0.0 & 0.0 & 0.2 & 1.6 & 0.5 & 4.2 \\
\hline Falcon 1.0 & 12.9 & 5.8 & 10.6 & 17.7 & 11.7 & 4.9 & 1.0 & 6.2 & 8.9 & 5.3 & 0.0 & 0.0 & 0.2 & 0.3 & 0.1 & 5.7 \\
\hline Juwel 1.0 & 12.5 & 3.8 & 14.1 & 17.6 & 12.0 & 12.3 & 2.0 & 4.8 & 0.0 & 4.8 & 0.0 & 0.0 & 0.9 & 2.3 & 0.8 & 5.9 \\
\hline F. Top 1.0 & 9.0 & 3.8 & 9.2 & 14.4 & 9.1 & 13.2 & 4.6 & 5.2 & 9.6 & 8.2 & 0.0 & 0.0 & 0.2 & 2.0 & 0.6 & 5.9 \\
\hline Falcon 0.8 & 12.3 & 6.7 & 17.8 & 19.6 & 14.1 & 6.2 & 5.5 & 1.2 & 2.5 & 3.8 & 0.0 & 0.0 & 1.1 & 2.0 & 0.8 & 6.2 \\
\hline Kolfugo 1.5 & 14.7 & 5.5 & 26.7 & 37.6 & 21.1 & 9.4 & 2.8 & 4.0 & 11.1 & 6.9 & 0.0 & 0.8 & 3.9 & 8.5 & 3.3 & 10.4 \\
\hline Amistar 1.0 & 20.1 & 12.3 & 25.1 & 26.3 & 21.0 & 14.8 & 2.3 & 11.6 & 9.0 & 9.4 & 0.0 & 0.3 & 2.2 & 7.8 & 2.6 & 11.0 \\
\hline $\begin{array}{l}\text { No fung. }{ }^{c} \\
\text { Mean }\end{array}$ & 14.9 & 8.9 & 21.8 & 22.7 & 17.1 & 9.5 & 6.6 & 18.0 & 20.7 & 13.7 & 0.0 & 0.0 & 4.5 & 13.8 & 4.6 & 11.8 \\
\hline $\begin{array}{l}\text { All } \\
\text { All }\end{array}$ & 11.4 & 5.5 & 14.0 & 19.5 & 12.6 & 7.7 & 2.7 & 5.4 & 8.5 & 6.1 & 0.0 & 0.1 & 1.2 & 3.8 & 1.3 & 6.5 \\
\hline $\begin{array}{l}\text { no fung. } \\
\text { LSD }\end{array}$ & 12.4 & 5.5 & 11.6 & 20.4 & 13.3 & 8.5 & 2.5 & 4.2 & 6.7 & 5.5 & 0.0 & 0.1 & 1.1 & 3.3 & 1.1 & 6.6 \\
\hline $\begin{array}{l}(P \leq 0.05)^{\mathrm{d}} \\
\text { Mean fung. } \\
\text { efficacy }\end{array}$ & 7.2 & 7.2 & 7.2 & 7.2 & 3.6 & 7.2 & 7.2 & 7.2 & 7.2 & 3.6 & ns & ns & $\mathrm{ns}$ & 7.2 & 3.6 & 2.1 \\
\hline$(\%)$ & 17.1 & 38.9 & 31.5 & 10.1 & 22.2 & 10.4 & 61.6 & 76.5 & 67.6 & 59.9 & 0 & 0 & 75.8 & 76.1 & 75.3 & 43.7 \\
\hline
\end{tabular}

${ }^{\mathrm{a}} \mathrm{Fc}=$ Fusarium culmorum and $\mathrm{Fg}=$ F. graminearum; $\mathrm{Cv}$. = cultivar mean and Over = overall mean; $\mathrm{ns}=$ not significant.

${ }^{\mathrm{b}}$ Abbreviations: $\mathrm{F} .=$ Folicur, Kolf. $=$ Kolfugo, fung. $=$ fungicide, All $=$ all treatments .

${ }^{c}$ Inoculated with fungus, but not sprayed with fungicide.

${ }^{\mathrm{d}} \mathrm{LSD}=$ least significant difference. 
ter/ha) + carbendazim (Kolfugo Super at 1.5 liters/ha) (Á. Mesterházy, unpublished data). These data indicate that efficacy of existing fungicides can be improved by combining fungicides.

Although the fungicides reduced the incidence of FHB in wheat, the data also demonstrate that the most effective fungicides may not provide satisfactory control. Hart et al. (14) and McMullen et al. (23) made the same observations. Additional research is needed to develop more effective fungicides, and new formulations or combinations of existing fungicides to improve plant protection.

In this study, cultivars were a significant source of variability, and there was a significant cultivar-fungicide interaction. Infection was higher on the more susceptible cultivars. In this experiment, Zugoly was the most susceptible cultivar; however, in Hungary, there are some durum wheat and $T$. aestivum accessions that are more susceptible. Fungicide efficacy was higher on the more resistant cultivars than the more susceptible cultivars. It is important that the most susceptible cultivars be identified and withdrawn from commercial production. The knowledge of resistance level of wheat cultivars has contributed to the development of cultivar-specific fungicide treatments to control FHB in Hungary (35).

Another source of variability of some fungicide studies is the inability to control the timing and level of inoculation, as well as the variation in the virulence of different isolates of the pathogen. Reliance on natural infection often fails to produce sufficient infection pressure, and it is not possible to evaluate specific isolates of the fungus. One approach has been to inoculate plots. In North America and China, corn is inoculated with $F$. graminearum and spread in the plot area $(14,25,46)$. Perithecia of Gibberella zeae, the perfect state of the fungus, develop on the inoculated corn shortly after the stem elongation and release ascospores that produce infection (47). Ascospore release and infection can be enhanced by mist irrigation. By inoculating the plots, the quantity of inoculum is greater and specific isolates can be evaluated. Although the timing of inoculation may be improved compared with natural infection, inoculation may still occur several times during and after the flowering and early grain-filling period. In addition, inoculation cannot be used for $F$. culmorum and other species that do not produce perithecia. It is possible to spray whole plots with a spore suspension to control the timing of inoculation, but to evaluate different inocula requires much more space. The microplot technique used in this study eliminates or reduces most of these problems.

Different isolates of Fusarium were used to evaluate their effect on disease development and to evaluate the efficacy of fungicides on different isolates. Fungicide efficacy varied with aggressiveness of the isolate. The correlations between isolates of $F$. graminearum and $F$. culmorum in fungicide efficacy were high in this test and in other experiments (35); therefore, the fungicides tested provided protection against the two main species of Fusarium associated with FHB.

The results in yield, percentage of damaged grains, and concentration of DON obtained in these microplot studies cannot be related directly to commercial production. Under commercial production, about one-third (unpublished data) of the damaged and shriveled grains are blown out of the combine, resulting in lower yield, fewer damaged grains, and lower DON concentration $(13,54)$. However, these results provide an indication on the efficacy of these fungicides in controlling FHB under ideal conditions. Research is being conducted to examine how the microplot technique can be used to better estimate the effect of FHB on yield, FDK, and DON concentration in producer fields.

Results on yield in this study also require careful evaluation. In this study, plots sprayed with a fungicide but not inoculated were used as one of the controls for comparisons. Fungicides that control FHB also will control leaf diseases. However, the microplot system allows us to measure yield response independently of leaf diseases. An evaluation of all diseases is needed.

In this study, the concentration of DON, FHB visual ratings, FDK severity, and yield loss were significantly correlated. Similar correlations between DON and FDK have been observed $(32,46)$. For fungicides that are moderately effective against FHB, a decrease in DON was not always detected on susceptible cultivars. Data from Germany showed that strobilurine fungicides can increase DON concentration (40), and lower than normal rates of fungicides increased DON in other studies (7). In this study, the application of azoxystrobin (Amistar) resulted in an increase in DON only in 1998. The role of fungicides in increasing DON levels in infected wheat requires additional research.

\section{ACKNOWLEDGMENTS}

We thank G. Shaner for his valuable evaluation of text and the fungicide producers for providing fungicides.

\section{LITERATURE CITED}

1. Anonymous 1993. Luttre contre les maladies. Les matieres actives blé. ITCF, Chopsir ses treatements 7 Octobre 1993.Paris, France.

2. Boyacioglu, D., Hettiarachchy, and Stack, R. W. 1992. Effect of three systemic fungicides on deoxynivalenol (vomitoxin) production by Fusarium graminearum in wheat. Can. J. Plant Sci. 72:93-101.

3. Caron, D. 1995. Les fongicides contre la fusariose des épis. Pourquoi leur efficacité estelle seulement moyenne? ITCF Perspect. Agric. 198:80-82.

4. Caron, D., Grossoleil, T., and Jugnet, M. P.
1990. La fusariose des épis. ITCF Perspect. Agric. 153:38-40

5. Daugenet, G. 1989. Fiches fongicides céréales et protéagineux 1989. ITCF Perspect. Agric. pp. 1-133.

6. Daguenet, G., Caron, D., and Maumene, C. 1991. La fusariose des épis. ITCF Perspect. Agric. 164:46-49.

7. D'Mello, J. P. F., Macdonald, A. M. C., Postel, D., Dijksma, W. T. P., Dujardin, A., and Placinta, C. M. 1998. Pesticide use and mycotoxin production in Fusarium and Aspergillus phytopathogens. Eur. J. Plant Pathol. 104:741-751.

8. Draper, M. A., Glover, K. D., Ruden, K. R., LeBouc, A. L., Schilling. S. M., and Lammers, G. 2002. Uniform fungicide performance trials in South Dakota-2002. Pages 67-68 in: 2002 National Fusarium Head Blight Forum, Erlanger, KY.

9. Fehrmann, H., and Diehl, Th. 1989. Partielle Taubährigkeit chemisch bekämpfen. Pflanzenschutz-Praxis 2:29-31.

10. Füzi, I. 2000. A helminthosporiumos levélszáradás, mint az õszibúza egyik fõ hazai károsítója (Drechslera leaf blight, a major pathogen of wheat in Hungary). (Abstr.) Page 94 in: Proc. Növényvédelmi Tud. Napok, Budapest.

11. Gareis, M., and Ceynowa, J. 1994. Einfluss des Fungicids Matador (Tebuconazole /Triadimenol) auf die Mykotoxinbildung durch Fusarium culmorum. Z. Lebensm. Unters. Forsch. 198:244-248.

12. Gregoire, T. D. 2002. An extension agronomist's experiences with fungicide application techniques to improve control of FHB. Page 96 in: 2002 National Fusarium Head Blight Forum, Erlanger, KY.

13. Jones, R. K., and Mirocha, C. J. 1999. Quality parameters in small grains from Minnesota affected by Fusarium head blight. Plant Dis. 83:506-511.

14. Halley, S., Pederson, J., McMullen, M., and Lukach, J. 1999. Sprayer modifications for enhanced control of Fusarium head blight with fungicides. Pages 51-52 in: 1999 National Fusarium Head Blight Forum, Sioux Falls, SD.

15. Hart, P., Froedtert, J., Ward, R., Siler, L., Van Ee, G., and Ledebuhr, R. 1999. Fungicide efficacy trials at Michigan State University. Pages 53-55 in: 1999 National Fusarium Head Blight Forum, Sioux Falls, SD.

16. Hart, P., VanEe, G., and Ledebuhr, R. 2001. Uniform fungicide trial collaborative study 2001-Michigan State University. Pages 5458 in: 2001 National Fusarium Head Blight Forum, Erlanger, KY.

17. Hershman, D. E., Bachi, P. R., TeKrony, D. M., and VanSanford, D. A. 2001. Management of Fusarium head blight in wheat using selected biological control agents and foliar fungicides, 2001. Pages 59-63 in: 2001 National Fusarium Head Blight Forum, Erlanger, KY.

18. Homdork S., Fehrmann, H., and Beck, R. 2000. Effects of field application of tebuconazole on yield, yield components and the mycotoxin content of Fusarium-infected wheat grain. J. Phytopathol. 148:1-6.

19. Hutcheon, J. A., and Jordan, V. W. L. 1992. Fungicide timing and performance for Fusarium control in wheat. Pages 633-636 in: Brighton Crop Protection Conference-Pests and Diseases, Brighton, UK

20. Maufras, J. Y., Maumené, C., Bourdin, M. M., and Leroux, M. M. 1994. Fongicides céréales et protéagineux 1994. ITCF. Paris, France.

21. Mauler-Machnik, A., and Suty, A. 1997. New findings on the epidemiology, importance and control of Fusarium ear blight on wheat. Cereal Res. Commun. 25:705-709. 
22. Mauler-Machnik, A., and Zahn, K. 1994. Ear fusarioses in wheat - new findings on their epidemiology and control with Folicur (tebuconazole). Pflanzenschutz-Nachr. Bayer (Ger. Ed.) 47:129-155.

23. McMullen, M., Milus, G., and Prom. L. 1999. 1999 uniform fungicide trials to identify products effective against Fusarium head blight in wheat. Pages 64-68 in: $1999 \mathrm{Na}-$ tional Fusarium Head Blight Forum, Sioux Falls, SD.

24. McMullen, M. P., Jones, R., and Gallenberg, D. 1997. Scab of wheat and barley: A reemerging disease of devastating impact. Plant Dis. 81:1340-1348.

25. McMullen, M. P., Schatz, B., Stover, R., and Gregoire, T. 1997. Studies on fungicide efficacy, application timing and application technologies to reduce Fusarium head blight and deoxynivalenol. Cereal Res. Commun. 25:779-780.

26. Mesterházy, Á., 1981. The role of aggressiveness of Fusarium graminearum isolates in the inoculation tests on wheat in seedling state. Acta Phytopathol. Acad. Sci. Hung. 16:281292

27. Mesterházy, Á. 1984. Fusarium species of wheat in South Hungary, 1970-1983. Cereal Res. Commun. 12:167-170.

28. Mesterházy, Á., 1985. Effect of seed production area on the seedling resistance of wheat to Fusarium seedling blight. Agronomie (Paris) 5:491-497.

29. Mesterházy, Á. 1987. Selection of head blight resistant wheat through improved seedling resistance. Plant Breed. 98:25-36.

30. Mesterházy, Á. 1995. Types and components of resistance against Fusarium head blight of wheat. Plant Breed. 114:377-386.

31. Mesterházy, Á. 1999. Fajtaspecifikus védekezés a búza kalászfuzáriuma ellen. (Cultivar specific control of Fusarium head blight in wheat). Agrofórum 10/5:13-16

32. Mesterházy, Á., and Bartók, T. 1996. Control of Fusarium head blight of wheat by fungicides and its effect on the toxin contamination of the grains. Pflanzenschutz-Nachr. Bayer (Ger. Ed.) 49:181-197.

33. Mesterházy, Á., and Bartók, T. 1997. Effect of chemical control on FHB and toxin contamination of wheat. Cereal Res. Commun. 25:781-783.
34. Mesterházy Á., and Bartók, T. 2001. Fungicide control of Fusarium head blight in wheat Pages 70-74 in: 2001 National Fusarium Head Blight Forum, Erlanger, KY.

35. Mesterházy, Á., Bartók, T., Mirocha, C. M., and Komoróczy, R. 1999: Nature of resistance of wheat to Fusarium head blight and deoxynivalenol contamination and their consequences for breeding. Plant Breed. 118:97-110.

36. Mielke, H., and Weinert, J. 1996. Investigations on the effect of various fungicides on the pathogen of partial head blight (Fusarium culmorum /W. G. Sm./ Sacc.). Nachrichtenbl. Pflanzenschutzdienst DDR 48:93-95.

37. Milus, E. A., and Parsons, C. E. 1994. Evaluation of foliar fungicides for controlling Fusarium head blight of wheat. Plant Dis. 78:697699.

38. Moss, M. O., and Frank, J. M. 1985. Influence of the fungicide tridemorph on T-2 toxin production by Fusarium sporotrichioides. Trans. Br. Mycol. Soc. 84:585-590.

39. Neto, N., and Giordani, N. A. 1989. Control quimico de la fusariosis en trigo. Pages 109118 in: Taller sobra la fusariosis de la espiga en America del Sur. M. M. Kohli, ed. CIMMYT, Mexico D. F.

40. Obst, A. Günther, B., Beck, R., Lepschy, J., and Tischner, H. 2002. Weather conditions conductive to Gibberella zeae and Fusarium graminearum head blight of wheat. J. Appl. Genet. 43A:185-192.

41. Obst, A., Lepschy-v Gleissenthall, J., and Beck, R. 1997. On the etiology of Fusarium head blight of $\mathrm{w}$ heat in South Germanypreceding crops, weather conditions for inoculum production and head infection, proneness of the crop to infection and mycotoxin production. Cereal Res. Commun. 25:699-704.

42. Papavizas, G. 1967. Evaluation of various media and antimicrobial agents for isolation of Fusarium from soil. Phytopathology 57:308-310.

43. Reis, E. M., Blum, M. M. C., and Casa, R. T. 1996. Chemical control of Gibberella zeae in wheat, a problem of deposition of fungicides on anthers. Summa Phytopathol. 22:39-42.

44. Shi J. R., Wang, Y. Z., Chen, H. G., and Shen, S. W. 1995. A preliminary study on synergetic action of the combination of triadimephon and carbendazim on Fusarium graminearum and its mechanism. Jiangshu J. Agric. Sci. 11:30-33.

45. Stack, R. W., and McMullen, M. P. 1995. A visual scale to estimate severity of Fusarium head blight in wheat. N. D. State Univ. Ext Ser. PP-1095.

46. Stack, R. W., McMullen, M. P., and Casper, H. 1997. Fusarium-damaged kernels and DON in the 1993 wheat crop in eastern North Dakota and northwestern Minnesota, USA. Cereal Res. Commun. 25:511-512.

47. Suty, A., and Mauler-Machnik, A. 1996. Fusarium head blight on wheat- new findings on the epidemiology and control of Gibberella zeae the teleomorph of Fusarium graminearum with Folicur. Pflanzenschutz-Nachr. Bayer (Engl. Ed.) 49:55-70.

48. Suty, A., Mauler-Machnik, A., and Courbon, R. 1996. New findings on the epidemiology of Fusarium ear blight on wheat and its control with tebuconazole. Pages 18-21 in: Brighton Crop Protection Conference: Pests and Diseases, Volume 2. Brighton, UK.

49. Sváb, J. 1973. Biometriai módszerek a kutatásban (Methods for Biometrics in Research). Mezőgazdasági Kiadó, Budapest.

50. Takegami, S., and Sasai, K. 1970. Investigations on resistance of wheat varieties to $G i b$ berella zeae after particular inoculation tech niques. X. Experiments on improved inoculation methods involving conidiospores and hyphae. Proc. Crop Sci. Soc. Jpn. 39:1-6.

51. Ueda, S., and Yoshizawa, T. 1988. Effect of tiophanat-methyl on the incidence of scab and the mycotoxin contamination in wheat and barley. Ann. Phytopathol. Soc. Jpn. 54:476482.

52. Wainwright, A., Jeitner, J., and Cazin-Bourguignon, P. 1992. Reduction in the wheat ear disease complex with tebuconazole sprays Pages 621-626 in: Brighton Crop Protection Conference: Pests and Diseases. Brighton, UK.

53. Weber E. 1967. Grundriss der biologischen Statistik. VEB Fisher Verlag, Jena. DDR (GDR).

54. Wilcoxson, R. D. 1996. Fungicides for control of Fusarium head blight-a review. Paper No. 22507 of the Minnesota Agric. Exp. Stn. University of Minnesota, Department of Plant Pathology, St. Paul. 